Available online at:

http://journal.unila.ac.id/index.php/tropicalsoil

DOI: $10.5400 /$ jts.2017.v22i1.11-20

\title{
Effectivity of Soil Amelioration on Peat Soil and Rice Productivity
}

\author{
Septiyana ${ }^{1}$, Atang Sutandi ${ }^{2}$ and Lilik Tri Indriyati ${ }^{2}$ \\ ${ }^{1)}$ Indonesian Soil Research Institute, Jl. Tentara Pelajar No 12A. Bogor (septie_azzahra@gmail.com) \\ ${ }^{2)}$ Department of Soil Science and Land Resources, Faculty of Agriculture, Bogor Agricultural University, Jl. Meranti \\ Kampus IPB Dramaga, Bogor 16680, Indonesia
}

Received 01 August 2016/ accepted 31 December 2016

\begin{abstract}
Application of ameliorant on peat soil has an important role on improving fertility status of peat soil via increasing soil $\mathrm{pH}$, reducing organic acids and toxic ions, and also increasing nutrients availability. Soil amelioration with polyvalent cations ( $\mathrm{Fe}, \mathrm{Al}, \mathrm{Cu}$, and $\mathrm{Zn}$ ) using slag, lateritic soils, and river mud are effective to reduce harmful effects of phenolic acids. The objective of the study was to determine the effect of soil amelioration on peat soil chemical properties and rice productivity (both biomass and yield). The study was consisted of two sets of experiments, namely soil incubation experiment conducted in the laboratory and a pot experiment conducted in the greenhouse. The experiment was designed in a complete randomized design (CRD) with 14 treatments and 4 replications. The results showed that the application of slag and dolomite as ameliorant showed a significant effect on increasing $\mathrm{pH}$, base saturation (BS), and the amount of exchangeable-Ca and - Mg. Moreover, slag application was better in improving chemical properties of peat soil as it increased $\mathrm{pH}$, base saturation (BS), and nutrient content (Ca, silica, ash and Fe). Application of burnt trass + dolomite (TD) showed no significant effect on increasing silica content in the peat soil. The application of slag resulted in the highest dry weight of biomass and grains of rice plants. The application of slag on peat soil in general provides better effects on the soil chemical conditions compared to that of trass, dolomite or ameliorant combination [trass + dolomite (TD) with slag].
\end{abstract}

Keywords: Ameliorant, organic acids, paddy, peat soil

\begin{abstract}
ABSTRAK
Amelioran berperan untuk memperbaiki kesuburan tanah gambut yaitu memperbaiki lingkungan akar bagi pertumbuhan tanaman melalui peningkatan $\mathrm{pH}$, menurunkan asam-asam organik dan ion-ion toksik, dan meningkatkan ketersediaan hara. Amelioran yang mengandung kation polivalen ( $\mathrm{Fe}, \mathrm{Al}, \mathrm{Cu}$, dan $\mathrm{Zn}$ ) seperti terak baja , tanah mineral laterit atau lumpur sungai sangat efektif mengurangi dampak buruk asam fenolat. Tujuan penelitian ini adalah mempelajari: 1) pengaruh aplikasi bahan amelioran dalam memperbaiki sifat kimia tanah gambut, 2) suhu pembakaran amelioran tras dan dolomit terhadap ketersediaan silika tanah gambut, 3) pengaruh aplikasi bahan amelioran terhadap pertumbuhan dan produksi (berat kering biomas dan berat kering gabah) tanaman padi. Penelitian terdiri atas dua percobaan, yaitu inkubasi sampel tanah dilakukan dilaboratorium dan percobaan rumah kaca dengan menggunakan rancangan acak lengkap (RAL) dengan 4 ulangan. Hasil penelitian yaitu 1) aplikasi amelioran slag dan dolomit berpengaruh nyata dalam meningkatkan $\mathrm{pH}$, kejenuhan basa $(\mathrm{KB})$, dan kadar hara $(\mathrm{Ca}$ dan $\mathrm{Mg}$ ), namun aplikasi slag lebih baik dalam memperbaiki kondisi kimia pada tanah gambut, selain meningkatkan pH, KB, kadar hara Ca, juga meningkatkan kadar silika, kadar abu dan Fe sebagai kation polivalen. 2) Pembakaran amelioran tras+dolomit (TD) tidak berpengaruh nyata dalam meningkatkan ketersedian kadar silika pada tanah gambut. 3)Aplikasi amelioran slag berpengaruh nyata dalam meningkatkan bobot kering biomas dan bobot kering gabah (BKG) pada tanaman padi. Amelioran terbaik yaitu slag dibandingkan tras, dolomit atau kombinasi [tras+dolomit (TD) dengan slag].
\end{abstract}

Kata kunci: Asam organik, bahan amelioran, silika, padi , tanah gambut

J Trop Soils, Vol. 22, No. 1, 2017: 11-20

ISSN 0852-257X 


\section{INTRODUCTION}

Increasing population has led to an increase of food production. Therefore, it is important to support national food security. However, nowadays the food production is decreasing due to the decrease of the number of productive agricultural land. Therefore, utilization of suboptimal land such as peatland for agricultural land purposes is necessary. Indonesia has the largest peatland among tropical countries, comprises of about 14.9 million ha, spreading mainly in Sumatra, Kalimantan and Papua (BB R \& D SDLP 2011).

However, the peatland utilization for agricultural development faces many limiting factors such as acidity, low base saturation, organic acid toxicity, and nutrient deficiency. Tadano et al. (1990) and Prasetyo (1996) reported that the low productivity of peat soils is mainly due to the high content of organic acids, which are toxic to plants, especially the derivatives of phenolic acids. Peatland development for agriculture must consider water regulation and ameliorant application since in most cases peatlands are generally inundated and infertile. Ameliorant has an important role on improving peat soil fertility such as increasing soil $\mathrm{pH}$, reducing the amount of organic acids and toxic ions, and increasing nutrients availability (Attiken et al. 1998). Soil amelioration with polyvalent cations $(\mathrm{Fe}, \mathrm{Al}, \mathrm{Cu}$, and $\mathrm{Zn}$ ) using slag, lateritic soils, and river mud effectively reduces harmful effects of phenolic acids (Sabiham and Ismangun 1997; Salampak 1999).

Rice plant requires very high amount of silica for its growth. According to Barker and Pilbeam (2007) silica is an essential nutrient for rice plant and rice plant absorbs silica approximately $150-300 \mathrm{~kg} \mathrm{Si}$ $\mathrm{ha}^{-1}$. Several studies have shown that application of trass and burned dolomite increased $\mathrm{pH}$, silica, and base cation content of peat soil. The untreated trass contained the lowest amount of $\mathrm{SiO}_{2}$, i.e. $0.043 \%$, whereas the combustion of trass at $105^{\circ} \mathrm{C}$ for 24 hours increased $\mathrm{SiO}_{2}$ content by $0.066 \%$, and the trass added with dolomite and burned at $700^{\circ} \mathrm{C}$ contained $0.149 \% \mathrm{SiO}_{2}$ (Meliala 2015).

The objectives of the study were to determine the effect of soil amelioration on peat soil chemical properties, to determine the effect of temperature of combustion of ameliorant trass and dolomite on the availability of silica in peat soil, and to determine the effect of soil amelioration on increasing crop productivity (both biomass and yield).

\section{MATERIALS AND METHODS}

\section{Experimental Setup}

The experiment was consisted of two parts, namely peat soil incubation experiment conducted in the laboratory and pot experiment using rice plants conducted in the greenhouse. The pot experiment was carried out at the Greenhouse Installation of the Soil Research Institute, the Center for Agricultural Land Resources, while the laboratory experiment was carried out at the Laboratory of the Department of Soil Science and Land Resources of Bogor Agricultural University (IPB). The research was conducted from December 2015 until November 2016.

\section{Material Characteristics Used in the Study}

Ameliorants used in this study were slag, dolomite, and trass. The type of slag used was iron furnace slag, which was rich in iron minerals with the $\mathrm{Fe}_{2} \mathrm{O}_{3}$ content of $42.6 \%$. The slag was obtained from PT Krakatau Steel. The dolomite used in this study was derived from carbonate sedimentary rocks consisting of two carbonate minerals namely calcite $\left(\mathrm{CaCO}_{3}\right)$ and magnesite $\left(\mathrm{MgCO}_{3}\right)$. The dolomite was obtained from Indo Bumi Agung Gresik. Trass derived from volcanic eruptions is rich in feldspar and silica, with the $\mathrm{SiO}_{2}$ content of $64.7 \%$, but the silica in the trass is very insoluble/ unavailable to plants. The trass was obtained from Cigombong Bogor Regency. The peat soil was taken from Dusun Karya Maju, Pematang Rahim Subdistrict, East Tanjung Jabung District, Jambi Province, Indonesia. The peat soil is classified as oligotrophic peat with the decomposition degree of sapric and peat thickness of $100 \mathrm{~cm}$.

\section{Experimental Design and Treatments}

Both the soil incubation experiment and pot experiment were conducted using a complete randomized design (CRD). The dosages of amerliorants applied in the peat soil incubation experiment are presented in Table 1. The dosages of macronutrient and micronutrient fertilizers used in this study were $267 \mathrm{~kg}$ urea ha ${ }^{-1}, 100 \mathrm{~kg} \mathrm{SP}-36$ $\mathrm{ha}^{-1}, 100 \mathrm{~kg} \mathrm{KCl} \mathrm{ha}{ }^{-1}, 10 \mathrm{~kg} \mathrm{CuSO}_{4} \mathrm{ha}^{-1}, 20 \mathrm{~kg}$ $\mathrm{ZnSO}_{4} \mathrm{ha}^{-1}$, and $20 \mathrm{~kg} \mathrm{FeSO}_{4} \mathrm{ha}^{-1}$. The treatment of trass-dolomite (TD) is a mixture of trass and dolomite with a ratio of $1: 1.5$, which is then burned at $700^{\circ} \mathrm{C}, 1000^{\circ} \mathrm{C}$ and $1200^{\circ} \mathrm{C}$. The dosage of ameliorant applied in each treatment was $5 \%$ of absolute dry weight (ADW) of peat soil. The amounts of available silica and total silica in the ameliorant materials used in this study were analyzed using yellow silicomolybdic acid method and gravimetric method, respectively.

In the incubation experiment, the weight of peat soil used was equivalent to 244 grams of absolute dry weight $(\mathrm{ADW})$ or equivalent to $1.0 \mathrm{~kg}$ of peat soil per pot, with the moisture content of $313 \%$. The 
Table 1. Dosages of ameliorants applied in the peat soil incubation experiment.

\begin{tabular}{|c|c|c|c|c|c|c|}
\hline Treatment & Trass & Dolomite & Slag & $\begin{array}{c}\text { TD } \\
\left(700^{\circ} \mathrm{C}\right)\end{array}$ & $\begin{array}{c}\text { TD } \\
\left(1000^{\circ} \mathrm{C}\right)\end{array}$ & $\begin{array}{c}\mathrm{TD} \\
\left(1200^{\circ} \mathrm{C}\right)\end{array}$ \\
\hline & \multicolumn{6}{|c|}{ 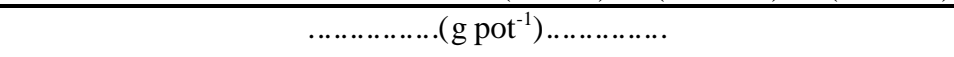 } \\
\hline Control & 0 & 0 & 0 & 0 & 0 & 0 \\
\hline Trass & 12.2 & 0 & 0 & 0 & 0 & 0 \\
\hline Slag & 0 & 0 & 12.2 & 0 & 0 & 0 \\
\hline Dolomite & 0 & 12.2 & 0 & 0 & 0 & 0 \\
\hline $100 \mathrm{TD} 700^{\circ} \mathrm{C}$ & $4.9^{*}$ & $7.3^{*}$ & 0 & 12.2 & 0 & 0 \\
\hline $100 \mathrm{TD} 1000^{\circ} \mathrm{C}$ & $4.9^{*}$ & $7.3^{*}$ & 0 & 0 & 12.2 & 0 \\
\hline 100TD $1200^{\circ} \mathrm{C}$ & $4.9^{*}$ & $7.3^{*}$ & 0 & 0 & 0 & 12.2 \\
\hline $75 \mathrm{TD} 700{ }^{\circ} \mathrm{C}+25 \mathrm{Slag}$ & $3.7^{*}$ & $5.5^{*}$ & 3.1 & 9.2 & 0 & 0 \\
\hline $75 \mathrm{TD} 1000^{\circ} \mathrm{C}+25 \mathrm{Slag}$ & $3.7^{*}$ & $5.5^{*}$ & 3.1 & 0 & 9.2 & 0 \\
\hline $75 \mathrm{TD} 1200^{\circ} \mathrm{C}+25 \mathrm{Slag}$ & $3.7^{*}$ & $5.5^{*}$ & 3.1 & 0 & 0 & 9.2 \\
\hline $50 \mathrm{TD} 700^{\circ} \mathrm{C}+50$ Slag & $2.4^{*}$ & $3.6^{*}$ & 6 & 6 & 0 & 0 \\
\hline $50 \mathrm{TD} 1000^{\circ} \mathrm{C}+50 \mathrm{Slag}$ & $2.4^{*}$ & $3.6^{*}$ & 6 & 0 & 6 & 0 \\
\hline $50 \mathrm{TD} 1200^{\circ} \mathrm{C}+50 \mathrm{Slag}$ & $2.4^{*}$ & $3.6^{*}$ & 6 & 0 & 0 & 6 \\
\hline
\end{tabular}

Note: The weight ratio of trass and dolomite in the mixed TD (trass + dolomite) treatment is 1:1.5.

ameliorants were mixed evenly with the peat soil according to the treatments, then incubated for 3 months in a flooded condition at the water height of $2-3 \mathrm{~cm}$ above the peat surface. No fertilizers were applied in the peat soil incubation experiment because we would like to determine the increase of nutrient content in the peat soil after the application of each ameliorant treatment. The incubated soil samples were taken, dried and then stored in a plastic bag for further analysis. The soil chemical properties including $\mathrm{pH}\left(\mathrm{H}_{2} \mathrm{O}\right)$, ash content, total-
$\mathrm{N}$ (Kjehldal), available-P (Bray-1), exchangeable cations $(\mathrm{Ca}, \mathrm{Mg}, \mathrm{K}, \mathrm{Na})$, base saturation, cation exchange capacity (CEC) $\left(\mathrm{NH}_{4} \mathrm{OAc} 1 N \mathrm{pH} 7\right)$, available micronutrients ( $\mathrm{Fe}, \mathrm{Cu}, \mathrm{Zn}, \mathrm{Mn}$, and $\mathrm{Pb}$ ) (DTPA pH 7.3), and $\mathrm{SiO}_{2}$ content (gravimetric method) were analyzed.

The weight of peat soil used in the pot experiment using rice plants was $3 \mathrm{~kg}$ of absolute dry weight (ADW) or equal to $12.5 \mathrm{~kg}$ of peat soil per pot, with a moisture content of $313 \%$. The ameliorants were mixed evenly with the peat soil

Table 2. Dosages of ameliorants applied in the pot experiment using rice plants.

\begin{tabular}{|c|c|c|c|c|c|c|}
\hline Treatment & Trass & Dolomite & Slag & $\begin{array}{l}\text { TD } \\
\left(700^{\circ} \mathrm{C}\right)\end{array}$ & $\begin{array}{l}\text { TD } \\
\left(1000^{\circ} \mathrm{C}\right)\end{array}$ & $\begin{array}{l}\text { TD } \\
\left(1200^{\circ} \mathrm{C}\right)\end{array}$ \\
\hline & \multicolumn{6}{|c|}{ 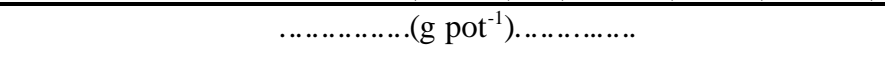 } \\
\hline control & 0 & 0 & 0 & 0 & 0 & 0 \\
\hline NPK standard ${ }^{* *}$ & 0 & 0 & 0 & 0 & 0 & 0 \\
\hline Trass & 150 & 0 & 0 & 0 & 0 & 0 \\
\hline Slag & 0 & 0 & 150 & 0 & 0 & 0 \\
\hline Dolomite & 0 & 150 & 0 & 0 & 0 & 0 \\
\hline $100 \mathrm{TD} 700^{\circ} \mathrm{C}$ & $60^{*}$ & $90^{*}$ & 0 & 150 & 0 & 0 \\
\hline $100 \mathrm{TD} 1000^{\circ} \mathrm{C}$ & $60^{*}$ & $90^{*}$ & 0 & 0 & 150 & 0 \\
\hline $100 \mathrm{TD} 1200^{\circ} \mathrm{C}$ & $60^{*}$ & $90^{*}$ & 0 & 0 & 0 & 150 \\
\hline $75 \mathrm{TD} 700^{\circ} \mathrm{C}+25 \mathrm{Slag}$ & $45^{*}$ & $68^{*}$ & 38 & 113 & 0 & 0 \\
\hline $75 T \mathrm{~T} 1000^{\circ} \mathrm{C}+25 \mathrm{Slag}$ & $45^{*}$ & $68^{*}$ & 38 & 0 & 113 & 0 \\
\hline $75 \mathrm{TD} 1200^{\circ} \mathrm{C}+25 \mathrm{Slag}$ & $45^{*}$ & $68^{*}$ & 38 & 0 & 0 & 113 \\
\hline $50 \mathrm{TD} 700^{\circ} \mathrm{C}+50 \mathrm{Slag}$ & $30^{*}$ & $45^{*}$ & 75 & 75 & 0 & 0 \\
\hline 50TD $1000^{\circ} \mathrm{C}+50 \mathrm{Slag}$ & $30^{*}$ & $45^{*}$ & 75 & 0 & 75 & 0 \\
\hline 50TD $1200^{\circ} \mathrm{C}+50 \mathrm{Slag}$ & $30^{*}$ & $45^{*}$ & 75 & 0 & 0 & 75 \\
\hline
\end{tabular}

Note: $*=$ The weight ratio of trass and dolomite in the mixed TD (trass + dolomite) treatment is 1:1.5.

$* *=$ Standard NPK treatment $(100 \%$ of recommended doses of macronutrient and micronutrient fertilizers) 
Table 3. Dosages of fertilizers applied in the pot experiment using rice plants.

\begin{tabular}{|c|c|c|c|c|c|c|}
\hline Treatment & Urea & SP-36 & $\mathrm{KCl}$ & $\mathrm{FeSO}_{4}$ & $\mathrm{CuSO}_{4}$ & $\mathrm{ZnSO}_{4}$ \\
\hline & \multicolumn{6}{|c|}{$\ldots \ldots \ldots \ldots \ldots . .\left(\mathrm{g} \mathrm{pot}^{-1}\right) \ldots \ldots \ldots \ldots \ldots$} \\
\hline Control & 0 & 0 & 0 & 0 & 0 & 0 \\
\hline NPK standard & 1.667 & 0.625 & 0.625 & 0.125 & 0.062 & 0.125 \\
\hline Trass & 0.834 & 0.313 & 0.313 & 0 & 0 & 0 \\
\hline Slag & 0.834 & 0.313 & 0.313 & 0 & 0 & 0 \\
\hline Dolomite & 0.834 & 0.313 & 0.313 & 0 & 0 & 0 \\
\hline $100 \mathrm{TD} 1000^{\circ} \mathrm{C}$ & 0.834 & 0.313 & 0.313 & 0 & 0 & 0 \\
\hline $100 \mathrm{TD} 1000^{\circ} \mathrm{C}$ & 0.834 & 0.313 & 0.313 & 0 & 0 & 0 \\
\hline 100TD $1200^{\circ} \mathrm{C}$ & 0.834 & 0.313 & 0.313 & 0 & 0 & 0 \\
\hline $75 \mathrm{TD} 700^{\circ} \mathrm{C}+25$ Slag & 0.834 & 0.313 & 0.313 & 0 & 0 & 0 \\
\hline $75 \mathrm{TD} 1000^{\circ} \mathrm{C}+25 \mathrm{Slag}$ & 0.834 & 0.313 & 0.313 & 0 & 0 & 0 \\
\hline $75 \mathrm{TD} 1200^{\circ} \mathrm{C}+25 \mathrm{Slag}$ & 0.834 & 0.313 & 0.313 & 0 & 0 & 0 \\
\hline $50 \mathrm{TD} 700^{\circ} \mathrm{C}+50 \mathrm{Slag}$ & 0.834 & 0.313 & 0.313 & 0 & 0 & 0 \\
\hline $50 \mathrm{TD} 1000^{\circ} \mathrm{C}+50 \mathrm{Slag}$ & 0.834 & 0.313 & 0.313 & 0 & 0 & 0 \\
\hline $50 \mathrm{TD} 1200^{\circ} \mathrm{C}+50 \mathrm{Slag}$ & 0.834 & 0.313 & 0.313 & 0 & 0 & 0 \\
\hline
\end{tabular}

according to the treatments, then incubated for 1 month in a flooded condition with the water height of $2-3 \mathrm{~cm}$ above the peat surface. The rice seedlings with the age of 15 days were planted. At the time of planting, the starter fertilizers, i.e. urea, SP-36, and $\mathrm{KCl}$ were applied. Urea was applied twice (half dosage of urea was applied at 7 days after planting (DAP) and the rest was applied at $30 \mathrm{DAP}$ ), while $\mathrm{KCl}, \mathrm{SP}-36$, and micronutrient fertilizers were applied simultaneously at the planting time. The treatment of urea, $\mathrm{KCl}, \mathrm{SP}-36$ fertilizers is referred to as standard NPK treatment, which is considered as $100 \%$ of recommended doses of macronutrient and micronutrient fertilizers, while in the ameliorant treatments the dosage of fertilizers applied was 50 $\%$ of the recommended dose of macronutrient fertilizers. The control treatment was performed without ameliorant and fertilizer application. The dosages of ameliorants and fertilizers applied in the pot experiment are presented in Table 2 and 3 . The rice plant variety IR-64 was used in the experiment. During the nurturing of rice plants, the water height was maintained at $2-3 \mathrm{~cm}$ above the surface of peat soil. The rice grains were harvested at 120-125 DAP or when $95 \%$ of rice grains turned to yellow. The plant parameters measured were the dry weight of rice plant biomass and dry weight of grains (DWG).

\section{Statistical Analysis}

The data were analyzed statistically using analysis of variance at 5\% significance level using SAS 9.4 software in order to determine the significant effect of the treatments on the observed variables. The treatments with a significant effect were further tested using Duncan Multiple Range Test (DMRT).

\section{RESULTS AND DISCUSSION}

\section{The Initial Chemical Properties of Peat Soil}

Table 4 showed that the $\mathrm{pH}$ of peat soil is very low/acidic; the macronutrient and micronutrient availability are low, except for the available-P and $\mathrm{Fe}$ (high) and the total-N content (medium); the cation exchange capacity (CEC) and base saturation (BS) are low. Based on the data in Table 4, the limiting factor of this peat soil is the low fertility level. The decomposition of woody materials rich in lignin in the peat soil occurs in an anaerobic state, producing aliphatic acids and phenolic acids in which most of these acids are toxic to plants (Kononova 1968; Tsutsuki dan Ponnamperuma 1987, Tsutsuki dan Kondo 1995). Several studies have shown that phenolic acids are phytotoxic to plants and able to inhibit plant growth (Driessen 1978; Steventson 1994, Tsutsuki 1984). Application of ameliorant, particularly the ameliorant that contains polyvalent cations such as $\mathrm{Fe}, \mathrm{Al}, \mathrm{Cu}$, and $\mathrm{Zn}$, on peat soil can be an option to improve the chemical properties of peat soil used as a planting medium.

\section{The Effects of Ameliorant Application on the Chemical Properties of Peat Soil}

The chemical properties of peat soil after ameliorant application in the soil incubation experiment are presented in Table 5. The soil $\mathrm{pH}$ was significantly affected by the ameliorant 
Table 4. Initial chemical properties of peat soil.

\begin{tabular}{lcl}
\hline Chemical properties & Value & Category \\
\hline $\mathrm{pH} \mathrm{H}_{2} \mathrm{O}$ & 3.2 & Very acid \\
Total-N(\%) & 1.7 & Medium \\
Available-P $(\mathrm{ppm})$ & 85.2 & High \\
Exchangeable-Ca $\left(\mathrm{cmol}(+) \mathrm{kg}^{-1}\right)$ & 7.7 & Low \\
Exchangeable-Mg(cmol $\left.(+) \mathrm{kg}^{-1}\right)$ & 2.3 & Low \\
Exchangeable-K(cmol $\left.(+) \mathrm{kg}^{-1}\right)$ & 0.3 & Low \\
Exchangeable-Na(cmol $\left.(+) \mathrm{kg}^{-1}\right)$ & 0.5 & Low \\
$\mathrm{CEC}\left(\mathrm{cmol}(+) \mathrm{kg}^{-1}\right)$ & 73.4 & Low \\
Base saturation $(\%)$ & 14.9 & Low \\
Available-Fe $(\mathrm{ppm})$ & 328.8 & High \\
Available-Cu $(\mathrm{ppm})$ & 0.5 & Low \\
Available- $\mathrm{Zn}(\mathrm{ppm})$ & 3.9 & Low \\
Available-Mn $(\mathrm{ppm})$ & 5.0 & Low \\
Available-Pb(ppm) & 1.3 & - \\
Ash $(\%)$ & 7.4 & Medium * \\
SiO $(\%)$ & 6.3 & - \\
\hline
\end{tabular}

Note: Parameter of peat soil chemical properties (Fleischer, Halim, Jones Jr 2001, Tim IPB 1976,Tim PPT 1983, In Fatmawati. 2013). * Classification of peat soil fertility level (Fleischer in Driessen \&Soepraptohardjo 1974).

application. The soil $\mathrm{pHs}$ in the control and trass treatments were very low, while the highest soil $\mathrm{pH}$ was observed in the dolomite treatment. This is due to the $\mathrm{Ca}$ and $\mathrm{Mg}$ in the dolomite are quickly dissolved and available, as well as due to the higher neutralizing power of the dolomite. According to Hardjowigeno (1986), dolomite can increase soil $\mathrm{pH}$ and soil base saturation as well as can add $\mathrm{Ca}$ and $\mathrm{Mg}$ into the soil. Meanwhile, the increase of $\mathrm{pH}$ after application of slag is probably caused by the ligand formation reaction between organic acids, such as carboxylic acids and phenolics, and hydroxyl groups of $\mathrm{Fe}$ and $\mathrm{Al}$ contained in the slag, liberating $\mathrm{OH}^{-}$that can increase the soil $\mathrm{pH}$. According to Suwarno and Goto (1997), the electric furnace slag has a $\mathrm{pH}\left(\mathrm{H}_{2} \mathrm{O}\right)$ of 11.1 and neutralizing power of $66.3 \%$. The result of this study is consistent with other findings that showed that electric furnace $(\mathrm{EF})$ slag from Indonesia can be used as lime to enhance the $\mathrm{pH}$ of acid soils as well as can be utilized as peat soil conditioner (Suwarno and Goto 1997; Suwarno 2002).

The amount of exchangeable-Ca and $-\mathrm{Mg}$ in the peat soil increased significantly after ameliorant application (Table 5). The highest amount of exchangeable-Ca and $-\mathrm{Mg}$ was observed after application of dolomite, while the lowest amount of exchangeable- $\mathrm{Ca}$ and $-\mathrm{Mg}$ was observed in the control and trass treatments. The increase of exchangeable- $\mathrm{Ca}$ and $-\mathrm{Mg}$ in the peat soil after dolomite application was due to the high contribution of $\mathrm{Ca}$ and $\mathrm{Mg}$ from the dolomite materials (30\% $\mathrm{CaO}$ and $18 \% \mathrm{MgO}$ ). The amount of exchangeable-
$\mathrm{Ca}$ in the peat soil applied with dolomite was not significantly different from that in the peat soil applied with slag. This is because the slag material also contains $\mathrm{Ca}(26 \% \mathrm{CaO})$ (Suwarno and Goto 1997). This result corresponds to the study of Huang et al. (2012), which stated that steel slag contains $\mathrm{CaO}$, $\mathrm{MgO}$, and $\mathrm{SiO}_{2}$, and application of steel slag can increase the $\mathrm{pH}$ and $\mathrm{Ca}$ content of acid soils. On the other hand, the amount of exchangeable-Na and $-\mathrm{K}$ in the peat soil was not significantly different among the treatments. The base saturation (BS) of peat soil was increased significantly after ameliorant application. The highest base saturation (BS) was measured in the dolomite treatment, while the lowest base saturation was observed in the control and trass treatments. The increase of base saturation in the peat soil was caused by the contribution of $\mathrm{Ca}$ and $\mathrm{Mg}$ from dolomite/slag materials. The ameliorant application showed no significant effect on the cation exchange capacity of peat soil.

Application of ameliorant showed a significant effect on the amount of available-P in the peat soil. In general, the amount of available-P decreased with increasing dosage of slag. The decrease of $P$ availability in the slag treatment was due to the present of an Fe polyvalent cation derived from slag material that led to an increase of bonding between $\mathrm{P}$ and organic acids via a cation bridge. According to Hartatik et al. (2004) the application of ameliorant is able to reduce $\mathrm{P}$ leaching in peat soils. This result is in line with the study of Rachim (1995) that suggested that $\mathrm{Al}$ and $\mathrm{Fe}$ cations in peat soil are 


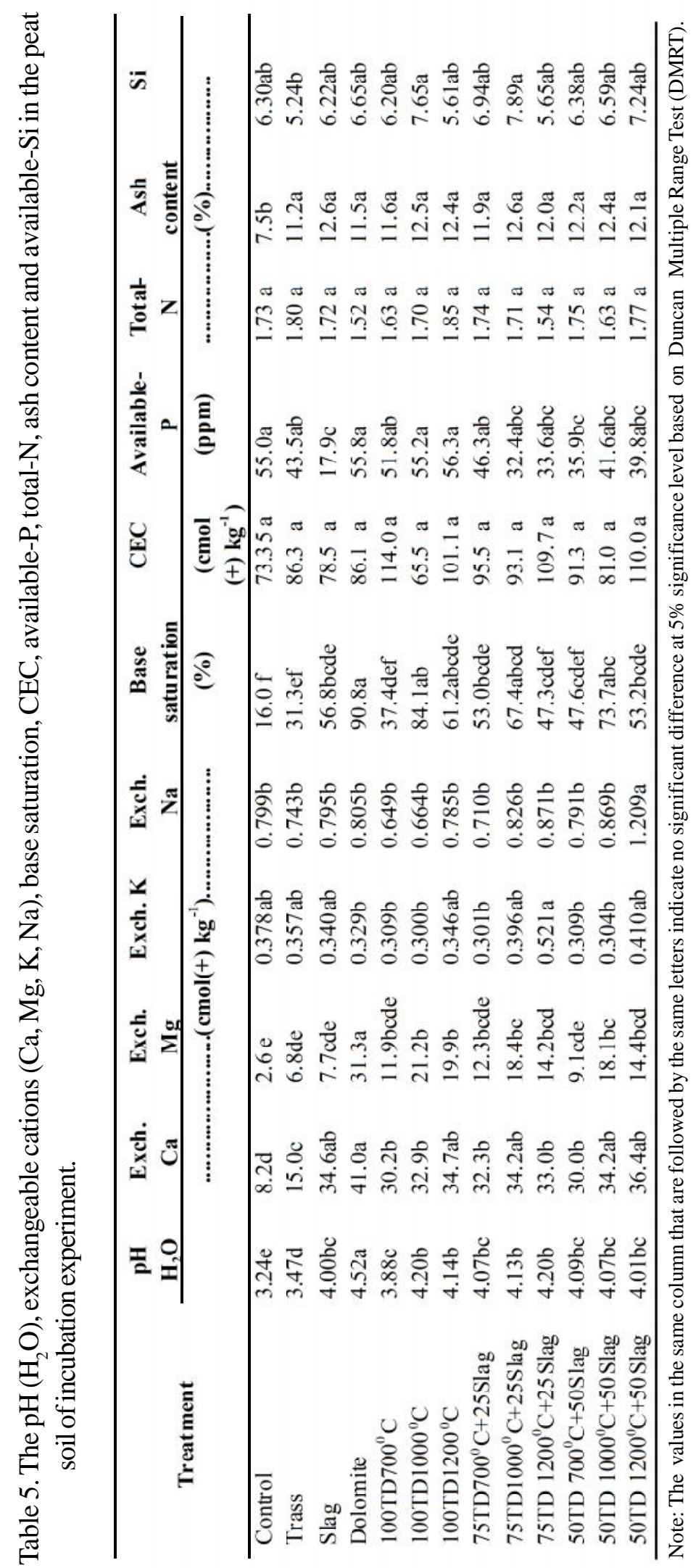


able to increase $\mathrm{P}$ retention compared to that without the cations. The limiting factor of peat soil as a planting medium of rice plants is not only $\mathrm{P}$ availability, but also other peat soil problems, such as organic acid toxicity (which causes the nutrients in the soil are easily leached and not available to plants), high acidity, and low macronutrient ( $\mathrm{Ca}$ and $\mathrm{Mg}$ ) and micronutrient content. On the other hand, the total-N content in the peat soil applied with ameliorant was not significantly different from that in the control treatment (Table 5).

Application of ameliorant significantly increased the ash content of peat soil. In general, the ash content increased with increasing dosage of slag. This is due to the contribution of balanced macro and micro nutrients derived from the slag material ( $\mathrm{Ca}, \mathrm{Mg}, \mathrm{Si}$, and $\mathrm{Fe}$ ). However, the ameliorant application did not affect the silica content in the peat soil. Yet in general, the silica content in the peat soil applied with ameliorant TD + slag increased with increasing dosage of the slag applied. This result is supported by the fact that the slag contains the highest total silica and available silica among other ameliorants (Table 6). According to Suwarno (2010), the electric furnace (EF) slag as a source of $\mathrm{Si}$ fertilizer for the rice plants is able to increase the growth and yield of rice plants grown on both low Si soil and peat soil.

\section{Concentrations of Micronutrients and Heavy Metals (Fe, Mn, $\mathrm{Cu}, \mathrm{Zn}$ and $\mathrm{Pb}$ ) in the Peat Soil}

The amounts of micronutrients and heavy metals $(\mathrm{Fe}, \mathrm{Mn}, \mathrm{Cu}, \mathrm{Zn}$ and $\mathrm{Pb}$ ) in the peat soil after ameliorant applications are presented in Table 7. The highest amount of $\mathrm{Fe}$ in the peat soil was obtained after slag application, which was increased with increasing dosage of slag. This is due to the high $\mathrm{Fe}$ content $\left(43.2 \% \mathrm{Fe}_{2} \mathrm{O}_{3}\right)$ in the slag material. The higher $\mathrm{Fe}$ content in the ameliorant in the form of a polyvalent cation, the more significant its function to reduce the adverse effects of phenolic acids. The formation of complexes between organic molecules and metal ions of more than one bond will usually increase the stability of the complexes. Thus, Fe is a cation that has high reactivity in interacting with organic acids, so the slag application can suppress the concentration of some phenolic acid derivatives contained in the peat soil. Meanwhile, the amount of $\mathrm{Mn}$ in the peat soil in general increased significantly after ameliorant application, particularly in the treatment of TD + slag. It may be due to the contribution of $\mathrm{Mn}$ from trass/slag material applied.

Ameliorant application showed no significant effect on the $\mathrm{Cu}$ content in the peat soil, and the lowest $\mathrm{Cu}$ content in the peat soil was observed in the slag treatment. In general, $\mathrm{Cu}$ content decreased with increasing dosage of slag. It might occur because of 3 factors: 1) $\mathrm{Cu}$ reacts with carbonate so that its activity decreases in the soil. According to Hao et al. (2012), application of steel slag is able to increase the dissolved carbonate in the soil, which further reacts with $\mathrm{Cu}$ to form $\mathrm{CuCO}_{3}$ and leads to the decrease of $\mathrm{Cu}$ activity; 2) A reaction occurs between organic acids with $\mathrm{Cu}$ so as to form a strong coordination bond (chelate). The formation of complex or chelate compounds between $\mathrm{Cu}$ and peat soil organic acids can suppress the adverse effects of phenolic and carboxylic acids (Zahrah 2010); 3) The $\mathrm{Cu}$ activity decreases along with the increase of $\mathrm{pH}$ of peat soil. According to Haihong et al. (2013), steel slag application can reduce soil acidity so as to reduce heavy metal activity and excessive micronutrients in the soil. Similarly, application of slag on peat soil resulted in lower availability of $\mathrm{Zn}$ compared to other treatments. The $\mathrm{Pb}$ content in the peat soil was quite low in all ameliorant treatments, and tended to decrease with increasing dosage of slag. Based on the criteria of heavy metal content in soil and plant proposed by the Soil Research Institute (2009), the $\mathrm{Pb}$ content in the peat soil used in this study is in the the normal range (2$300 \mathrm{mg} \mathrm{kg}^{-1}$ ), while the critical limit of $\mathrm{Pb}$ content in soil is about $100-400 \mathrm{mg} \mathrm{kg}^{-1}$. According to Soepardi (1983), the concentration of $\mathrm{Pb}$ in soil decreases along with the application of ameliorant slag and dolomite. In addition, the application of ameliorant

Table 6. The amounts of available silica and total silica in the ameliorants.

\begin{tabular}{lcc}
\hline \multirow{2}{*}{ Ameliorant } & Available $\mathrm{Si}$ & $\mathrm{Total}_{\mathrm{SiO}}$ \\
\cline { 2 - 4 } & \multicolumn{2}{c}{$(\%)$} \\
\hline Tras & 0.328 & 84.05 \\
Dolomite & 0.135 & 13.92 \\
Slag & 2.468 & 31.86 \\
Trass+Dolomit (TD) $700^{\circ} \mathrm{C}$ & 0.276 & 14.30 \\
Trass+Dolomit (TD) $1000^{\circ} \mathrm{C}$ & 0.044 & 17.78 \\
Trass+Dolomit (TD) $1200^{\circ} \mathrm{C}$ & 0.035 & 40.62 \\
\hline
\end{tabular}


Table 7. The concentrations of micronutrients ( $\mathrm{Fe}, \mathrm{Mn}, \mathrm{Cu}$ dan $\mathrm{Zn}$ ) and $\mathrm{Pb}$ in the peat soil of incubation experiment.

\begin{tabular}{|c|c|c|c|c|c|}
\hline \multirow[t]{2}{*}{ Treatment } & \multirow[t]{2}{*}{$\mathrm{Fe}$} & $\mathrm{Mn}$ & $\mathrm{Cu}$ & $\mathrm{Zn}$ & $\mathrm{Pb}$ \\
\hline & & \multicolumn{4}{|c|}{ (n) } \\
\hline Control & $379 \mathrm{~cd}$ & $4.7 \mathrm{~h}$ & $0.275 \mathrm{ab}$ & $3.74 \mathrm{a}$ & $1.43 \mathrm{a}$ \\
\hline Trass & $507 \mathrm{c}$ & $23.5 \mathrm{fgh}$ & $0.227 \mathrm{abc}$ & $4.17 \mathrm{a}$ & $1.37 \mathrm{ab}$ \\
\hline Slag & 966 a & $19.6 \mathrm{gh}$ & $0.020 \mathrm{c}$ & $0.10 \mathrm{~b}$ & $0.35 \mathrm{~d}$ \\
\hline Dolomite & $228 \mathrm{~d}$ & $21.7 \mathrm{fgh}$ & $0.213 a b c$ & $3.00 \mathrm{a}$ & $1.46 \mathrm{a}$ \\
\hline $100 \mathrm{TD} 700^{\circ} \mathrm{C}$ & $324 \mathrm{~cd}$ & 26.4 efgh & $0.289 \mathrm{ab}$ & $3.00 \mathrm{a}$ & $1.35 \mathrm{ab}$ \\
\hline 100TD $1000^{\circ} \mathrm{C}$ & $325 \mathrm{~cd}$ & 42.9 defg & $0.123 \mathrm{abc}$ & $3.53 \mathrm{a}$ & $1.44 \mathrm{a}$ \\
\hline 100TD $1200^{\circ} \mathrm{C}$ & $352 \mathrm{~cd}$ & 40.7 defg & $0.324 \mathrm{a}$ & $3.93 \mathrm{a}$ & $1.45 \mathrm{a}$ \\
\hline 75TD $700^{\circ} \mathrm{C}+25$ Slag & $707 \mathrm{~b}$ & $85.6 \mathrm{ab}$ & $0.158 \mathrm{abc}$ & $3.97 \mathrm{a}$ & $1.34 \mathrm{ab}$ \\
\hline 75TD $1000^{\circ} \mathrm{C}+25$ Slag & $745 \mathrm{~b}$ & $102.2 \mathrm{a}$ & $0.233 a b c$ & $5.01 \mathrm{a}$ & $1.48 \mathrm{a}$ \\
\hline 75TD $1200^{\circ} \mathrm{C}+25$ Slag & $695 \mathrm{~b}$ & $66.3 \mathrm{bcd}$ & $0.116 a b c$ & $4.08 \mathrm{a}$ & $1.13 \mathrm{abc}$ \\
\hline $50 \mathrm{TD} 700{ }^{\circ} \mathrm{C}+50$ Slag & $791 \mathrm{ab}$ & 56.2 bcde & $0.100 \mathrm{bc}$ & $3.95 \mathrm{a}$ & $0.98 \mathrm{bc}$ \\
\hline 50TD $1000{ }^{\circ} \mathrm{C}+50$ Slag & $872 \mathrm{ab}$ & $77.7 \mathrm{abc}$ & $0.137 \mathrm{abc}$ & $3.94 \mathrm{a}$ & $1.10 \mathrm{abc}$ \\
\hline 50TD $1200^{\circ} \mathrm{C}+50$ Slag & $778 \mathrm{~b}$ & 53.0 cdef & $0.214 \mathrm{abc}$ & $4.31 \mathrm{a}$ & $0.87 \mathrm{c}$ \\
\hline
\end{tabular}

Note: The values in the same colum that are followed by the same letters indicate no significant difference at $5 \%$ significance level based on DMRT.

Table 8. Dry weight of biomass and grains of rice plants obtained in the greenhouse experiment.

\begin{tabular}{|c|c|c|}
\hline \multirow{2}{*}{ Treatment } & Dry biomass weight & Dry weight of grain \\
\hline & \multicolumn{2}{|c|}{$\mathrm{Mg} \mathrm{ha}^{-1}$} \\
\hline Control & $0.06 \mathrm{~g}$ & $0.06 \mathrm{f}$ \\
\hline Standard (NPK) & $0.52 \mathrm{~g}$ & $0.37 \mathrm{ef}$ \\
\hline Trass & $0.14 \mathrm{~g}$ & $0.07 \mathrm{f}$ \\
\hline Slag & $4.66 \mathrm{a}$ & $4.11 \mathrm{a}$ \\
\hline Dolomite & $2.64 \mathrm{def}$ & $1.53 \mathrm{~cd}$ \\
\hline 100TD $700{ }^{\circ} \mathrm{C}$ & $1.88 \mathrm{f}$ & $1.00 \mathrm{def}$ \\
\hline 100TD $1000{ }^{\circ} \mathrm{C}$ & $2.14 \mathrm{ef}$ & $1.22 \mathrm{de}$ \\
\hline 100TD $1200^{\circ} \mathrm{C}$ & 2.92 cde & $1.96 \mathrm{bcd}$ \\
\hline $75 \mathrm{TD} 700{ }^{\circ} \mathrm{C}+25$ Slag & $2.23 \mathrm{ef}$ & $1.50 \mathrm{~cd}$ \\
\hline 75TD $1000{ }^{\circ} \mathrm{C}+25$ Slag & 2.86 cde & $1.86 \mathrm{~cd}$ \\
\hline 75TD $1200{ }^{\circ} \mathrm{C}+25$ Slag & $3.27 \mathrm{bcd}$ & $1.47 \mathrm{~cd}$ \\
\hline $50 \mathrm{TD} 700{ }^{\circ} \mathrm{C}+50$ Slag & $3.94 \mathrm{ab}$ & $2.98 \mathrm{~b}$ \\
\hline 50TD $1000{ }^{\circ} \mathrm{C}+50$ Slag & $3.62 \mathrm{bc}$ & $2.48 \mathrm{bc}$ \\
\hline 50TD $1200^{\circ} \mathrm{C}+50$ Slag & $3.68 \mathrm{bc}$ & $3.03 \mathrm{~b}$ \\
\hline
\end{tabular}

Note: The values in the same column that are followed by the same letters indicate no significant difference at $5 \%$ significance level based on DMRT.

slag and dolomite increases the soil $\mathrm{pH}$ and affects the low solubility of heavy metals (less mobile in soil and less available to plant).

\section{Effect of Ameliorant Application on the Dry Weight of Plant Biomass and Grains}

The application of ameliorant on the peat soil significantly increased the dry weight of rice plant biomass and dry weight of grains, except for that in the NPK standard and trass treatments. In the control, NPK standard and trass treatments, the rice plants suffered stunting and some were died, resulting in low plant biomass and yield. This phenomenon is influenced by the phenolic acids in the peat soil that is phytotoxic (toxic to the plant), thus inhibit the growth of plant. Phenolic acids can damage the root cells of plant so that the amino acids and other materials flow out of the cells thereby inhibiting root growth and nutrient uptake, as a result, the growth of the plant is stunted, the leaves suffered chlorosis 
then eventually the plant will die (Driessen 1978). The highest dry weight of rice plant biomass and grains was obtained in the peat soil applied with slag. Moreover, the increased dosage of slag applied on the peat soil resulted in an increase of plant biomass and grains. The yields of rice plants are presented in Table 8 .

The slag application on peat soil has advantages over other ameliorants in increasing rice plant biomass and grain production. This is due to the balanced macro and micro nutrients content in the slag material, besides the presence of $\mathrm{Fe}(43.20 \%$ $\mathrm{Fe}_{2} \mathrm{O}_{3}$ ) in the form of a polyvalent cation, in which the function of the polyvalent cation is to reduce the adverse effects of toxic organic acids. Polyvalent cations can form a coordination bond with organic ligands to form complex/chelate compounds, so that the nutrients present in the soil solution are not easily leached and can be absorbed optimally by plant. The application of slag as an ameliorant on peat soil also increased $\mathrm{pH}$, base saturation (BS), exchangeable$\mathrm{Ca}$, Fe content, silica and soil ash content, however, it decreased $\mathrm{Cu}, \mathrm{Zn}$, and $\mathrm{Pb}$ content in the peat soil. Electric furnace (EF) slag is able to provide balanced macro and micro nutrients to the peat soil. Therefore, slag application on peat soil can improve soil chemical conditions to support the growth and production of rice plants optimally.

\section{CONCLUSIONS}

The application of slag and dolomite as ameliorant on peat soil shows a significant effect on increasing $\mathrm{pH}$, base saturation (BS), and exchangeable-Ca and -Mg content. Moreover, slag application is better in improving the chemical properties of peat soil, i.e. the increase of $\mathrm{pH}$, base saturation (BS), and nutrient content (Ca, silica, ash and $\mathrm{Fe}$ ). Application of burnt trass + dolomite (TD) shows no significant effect on increasing silica content in the peat soil. The application of slag results in the highest dry weight of biomass and grains of rice plants. The application of slag on peat soil in general provides better effects on the soil chemical conditions compared to that of trass, dolomite or ameliorant combination [trass + dolomite (TD) with slag].

\section{REFERENCES}

Attiken WP, PW Moody and T Dickson. 1998. Field amelioration of acid soil in South East Queensland. I. Effect of amendments on soil properties. Austr J Agric Res 49: 627-638.
Balai Penelitian Tanah. 2009. Petunjuk teknis analisis kimia tanah, tanaman, air, dan pupuk. Balai Penelitian Tanah, Badan Penelitian dan Pengembangan Pertanian, Departemen Pertanian. Bogor (in Indonesian).

BB Litbang SDLP (Balai Besar Penelitian dan Pengembangan Sumberdaya Lahan Pertanian. 2011. Laporan tahunan. 2011. Konsorsium penelitian dan pengembangan perubahan iklim pada sektor pertanian. Balai Pesar Penelitiandan Pengembangan Sumberdaya Lahan Pertanian, Bogor (in Indonesian).

Barker AV and DJ Pilbeam. 2007. Handbook of Plant Nutrition. Boca Raton(US): CRC Pr.

Driessen PM, Soepraptohardjo 1974. Organic soil. In: Soil for agricultural expansion in Indonesia. ATA 106 Bulettin. Soil Reseach Institute Bogor.

Driessen PM. 1978. Peat soils. In: Soils and Rice. International Rice Research Institute, Los Banos, pp. 763-779.

Fatmawati E. 2013. Pemanfaatan tras sebagai pupuk silika dan pemberian dolomit untuk padi di tanah gambut dari Kumpeh, Jambi [Skripsi]. Institut Pertanian Bogor, Bogor (in Indonesian).

Haihong GU, LI Fuping, GUAN Xiang, LI Zhongwei and YU Qiang. 2013. Remediation of steel slag on acidic soil contaminated by heavy metal. Asian Agric Res 5: $100-104$.

Hao QIU, GU Haihong, HE Erkai, WANG Shizhong, and QIU Rongliang. 2012. Attenuation of metal bioavailability in acidic multi-metal contaminated soil treated with fly ash and steel slag. Pedosphere 22: 544-553.

Hardjowigeno S. 1986. Sumber Daya Fisik Wilayah dan Tata Guna Lahan: Histosol. Fakultas Pertanian Institut Pertanian Bogor (in Indonesian).

Hartatik W, K Idris, S Sabiham, S Djuniwati and JS Adiningsih. 2004. Peningkatan ikatan P dalam kolom tanah gambut yang diberi bahan amelioran tanah mineral dan beberapa jenis fosfat alam. J Tanah dan Lingkungan 6: 22-30 (in Indonesian).

Huang Y, X Guoping, H Cheng, J Wang, Y Wan and H Chen. 2012. An overview of utilization of steel slag. Procedia Environ Sci 16: 791-801.

Kononova MM. 1968.Transformation of organic matter and their relation to soil fertility. Sov Soil Sci 8:1047-1056.

Meliala SB. 2015. Usaha peningkatan kelarutan Si dari trass sebagai amelioran tanah gambut [skripsi]. Fakultas Pertanian, Institut Pertanian Bogor (in Indonesian).

Prasetyo TB. 1996. Perilaku asam-asam organik meracun pada tanah gambut yang diberi garam $\mathrm{Na}$ dan beberapa unsur mikro dalam kaitannya dengan hasil padi. Disertasi. Program Pascasarjana, Institut Pertanian Bogor (in Indonesian).

Rachim A. 1995. Penggunaan kation-kation polivalen dalam kaitannya dengan ketersediaan fosfat untuk meningkatkan produksi jagung pada tanah gambut. [Disertasi]. Program Pascasarjana, Institut Pertanian Bogor (in Indonesian). 
Sabiham S and Ismangun. 1997. Potensi dan kendala pengembangan lahan gambut untuk pertanian. Makalah pada Kongres VI PERAGI, 24-26 Juni 1997. Jakarta (in Indonesian).

Salampak. 1999. Peningkatan produktivitas tanah gambut yang disawahkan dengan pemberian amelioran tanah mineral berkadar besi tinggi. [Disertasi]. Program Pascasarjana, IPB. Bogor. 171p (in Indonesian).

Soepardi G. 1983. Sifat dan ciri tanah. Departemen Ilmu Tanah. Fakultas Pertanian. Institut Pertanian Bogor. Bogor (in Indonesian).

Stevenson FJ. 1994. Humus chemistry. Genesis, composition, and reactions. John Wiley and Sons, Inc. New York. 443 p.

Suwarno and I Goto. 1997. Mineralogical and chemical properties of Indonesia electric furnace slag and its application effect as soil amendment. J Agric Sci 42: $151-162$

Suwarno. 2002. Utilization of steel slag in wetland rice cultivation on peat soil. In Proceedings of the International Symposium on Land Management and Biodiversity in South East Asia, Bali. pp. 211-215
Suwarno. 2010. Pemanfaatan steel slag Indonesia di bidang Pertanian. J Ilmu Tanah dan Lingkungan 12: 36-41 (in Indonesian).

Tadano KB, K Ambak, T Yonebayashi, P Hara, C Vijarnsom, Nilnond and S Kawaguchi. 1990. Nutritional factors limiting crop growth in tropical peat soils. In: Soil Constrains on Sustainable Plant Production in the Tropics. Proc. $24^{\text {th }}$ Inter Symp Tropical Agric Res. Kyoto.

Tsutsuki K. 1984. Volatile products and low-molecular-weight products of the anaerobic decomposition of organic matter. Inter. Rice Res. inst, Soil Organic Matter. pp. 329-343.

Tsutsuki K and FN Ponnamperuma. 1987. Behavior of anaerobic decomposition products in submerged soils. Soil Sci Plant Nutr 3: 13-33.

Tsutsuki K and R Kondo. 1995. Lignin-derived phenolic compounds in different types of peat profiles in Hokkaido. Japan Soil Sci Plant Nutr 41: 515-527.

Zahrah S. 2010. Serapan hara N, P, K, dan hasil berbagai varietas tanaman padi sawah dengan pemberian amelioran ion $\mathrm{Cu}, \mathrm{Zn}$, Fe pada tanah gambut. J Natur Indonesia 12: 102-108. 